Article

\title{
Social Life Cycle Assessment as a Management Tool: Methodology for Application in Tourism
}

\author{
Gabriella Arcese *, Maria Claudia Lucchetti and Roberto Merli \\ Department of Business Studies, Roma Tre University, Via Silvio D’Amico, Rome 77- 00145, Italy; \\ E-Mails: mariaclaudia.lucchetti@uniroma3.it (M.C.L.); roberto.merli@uniroma3.it (R.M.) \\ * Author to whom correspondence should be addressed; E-Mail: gabriella.arcese@uniroma3.it; \\ Tel.: +39-06-5733-5713; Fax: +39-06-5733-5797.
}

Received: 25 March 2013; in revised form: 15 July 2013 / Accepted: 16 July 2013 /

Published: 2 August 2013

\begin{abstract}
As is widely known, sustainability is an important factor in competition, increasing the added value of a company in terms of image and credibility. However, it is important that sustainability assessments are effectively addressed in a global perspective. Therefore, life cycle tools are adopted to evaluate environmental and social impacts. Among these, and of particular significance, appears the Social Life Cycle Assessment (SLCA), which, although in its early stage of development, seems to have extremely promising methodological features. For this reason, it seemed interesting to propose a first application to the tourism sector, which could be better than other methods, studied in terms of social sustainability data. The particular characteristics of service delivery lend themselves more to the development of data related to social sustainability than other sectors. In this paper the results of a case study carried out using social accounting and business management tools are shown.
\end{abstract}

Keywords: tourism business evaluation; social life cycle assessment; social impacts; social responsibility

\section{Introduction}

The attention towards social, economic, and environmental issues, for the creation of sustainable development patterns increases the value of a company in terms of image and credibility with customers and business partners. Sustainability is therefore an important factor for competitiveness and 
integration within the local community, and for all the stakeholders. Corporations have become indispensable members of our society who need to be "incorporated" socially as well as legally. Recent institutional changes have made social and environmental sustainability an important source of institutional legitimacy of corporations [1].

For this reason, in the last year, the attention paid by authors to corporate governance has not only increased, but the notion has also broadened considerably and started to cover some aspects traditionally seen as being part of corporate social responsibility (CSR). This is based on the assumption that such standards increase legitimacy among stakeholders [2].

The SA8000 [3] was the first auditable social standard and is based on international workplace norms of the International Labour Organisation (ILO) as well as the Universal Declaration of Human Rights of the United Nations in order to improve the working conditions in practical life [4].

The CSR and the Social Accountability and its standards, such as SA8000 [3], have been theorized and standardized to support the social ethical engagement of companies, which seek to find a general consensus. Economic reasons also fostered the development of this standard [5]. Social impacts' evaluation is one of the cornerstones of product sustainability. Models of indicators designed to assess the social sustainability are many and different in nature and composition, although some studies show that these are still incomplete and most of them are not objective.

With this in mind, Social Life Cycle Assessment focuses on studying the social impacts of life cycles but, as this is a relatively new analytical approach, no globally shared application tools have been developed yet. Because of their specific service features, touristic activities are well suited for the elaboration of data related to social sustainability.

The Social Life Cycle Assessment methodology (SLCA) can be described as a tool that allows a strategic vision and management of the social sustainability of a product and takes the form of an analysis that allows the company to examine the social impact of the product through its sustainability evaluation, throughout the life cycle [6].

\section{Objective of the Study}

The aim of this study has been the analysis of the social impact of an accommodation facility, through the simultaneous application of existing Social Life Cycle Assessment tools, with data resulting from social accounting and business management tools, in order to point out the social criticalities of the organization. Explaining the applied methodology, we describe and evaluate the specific questionnaire utilized, and finally present a case study based on the application to an accommodation facility.

The purpose of this paper is to propose a questionnaire to conduct the interviews necessary for the information storage retrieval. It has been designed with the aim of containing all the necessary information to conduct a complete and comprehensive analysis of the social impacts. The subsequent SLCA application to the case study simply serves to test and demonstrate the real utility and reliability of the questionnaire.

The application to an accommodation facility of a structured model-for the detection and monitoring of social sustainability - centered on the life cycle approach, as it highlights the level of sustainability (as already verified for environmental sustainability), is able to offer higher quality 
service to customers, and remains most impressive in their experiences-offering a significant contribution to customer retention and thus establishing the foundations for long-term economic sustainability $[7,8]$. The ultimate objective for conducting an SLCA is to promote the improvement of social conditions, and of the overall socio-economic performance of a product throughout its life cycle on behalf of the stakeholders [7].

\section{Theoretical Review: Life Cycle Assessment and Social Aspects}

The Life Cycle Assessment (LCA), in regards to the recognition of environmental aspects, appears to be a consolidated tool on the international scenario, but its use still presents some critical points and the opportunity for further developments. The application of LCA to the social aspects of a product still presents an evolving, or totally new, approach [9].

Discussions on how to handle social and socio-economic criteria of products throughout a product life cycle started in the 1980s [10]. At that time, in Germany, a specific project Group on Ecological Economics was started within the ÖkoInstitut, and in the Society of Environmental Toxicology and Chemistry (SETAC) Workshop, reported a conceptual framework for the impact classifications, already including social aspects for holistic assessment [11].

In recent years, thanks to the support of various international organizations, the SLCA, less considered through the historical development of Life Cycle Thinking theories at first, assumed a growing importance, highlighting some improvement and completion needs for a methodology that is still at a preliminary stage [12].

The SLCA is defined as the methodology for the assessment of positive and negative social impacts that are generated by a product/service in its life cycle, and in relation to different groups of stakeholders involved, with the aim of promoting the improvement of a product's socio-economic performance throughout its life cycle [12].

The SLCA has not yet been formalized in an international standard. For this reason, the methodology refers to the steps proposed by the ISO $14040[13,14]$ standard on Environmental Life Cycle Assessment and its application, according to guidelines drawn up by SETAC in collaboration with the UNEP (United Nations Environment Program), [15,16]. Although the methodology is at an early stage of development, examples of its application to specific products can already be found in literature, and well-known research centers have proposed various approaches of qualitative and semi-quantitative analysis [17]. On the other hand, it is important to point out the existence of other analytical models that use different approaches and indicators, in connection with the three different ways in which SLCA can have an improvement effect as outlined: consequential SLCA, educational SLCA, and managerial SLCA. Many empirical and theoretical studies, in relevant fields of research, have been conducted in order to evaluate the claimed improvement effect of the three SLCA models, and some critical aspects were put in evidence for all the three methods $[18,19]$.

\section{Focus on Sustainability on Tourism and Accommodation Facility}

Tourism has been defined as “... the sum of the phenomena and relationships resulting from travel and stay of non-residents..." [20]. Even if mass consumption is endangering the future of our world in many different ways - and tourism has significantly contributed to this situation-tourism 
development can also bring extensive benefits to society. In an attempt to promote sustainable practices, different kinds of eco-labeling in this sector have been developed [21]. Tourism is a complex sector, characterized by the combination of activities encompassing areas as diverse as energy, agriculture, transport, etc. For this reason, the sector's relationship with sustainability has gradually consolidated, given the increasing importance of consumption and its environmental impacts [22,23]. Sustainability appears to be a key business variable for tourism.

As evidence of this, data on the European Ecolabel granting for accommodation facilities show a significant development in Italy: 157 licenses in October 2011, with a trend of strong growth in the period 2004-2009, and a decrease between 2009 and 2011, probably resulting from the introduction of the new EU Ecolabel criteria specific to this sector, which required a new effort of alignment for many facilities, in addition to being the category with the highest number of total licenses.

Despite the diffusion of the European Ecolabel for tourism, the real commitment of this sector-in the direction of social sustainability and the achievement of a strong sustainability, intended as the right conjugation of environmental, economic, and social aspects-still remain generally inadequate [24]. A sustainable accommodation consists of personal and professional, sensitive to a proper social and environmental management, in response to business needs and customer satisfaction [25].

Small firms often show relevant skills in managing these relationships, since they represent an integral and visible part of the community in which they operate [26].

\section{The Theoretical Framework}

Social impacts are consequences of positive or negative pressures on social endpoints (i.e., the well-being of stakeholders). When referring to the causes of social impacts, this generally implies three dimensions: behaviours; social and economic processes; and social, cultural, and human capital. These three dimensions have direct and dynamics correlations [9]. The aim of SLCA is to be the method to assess the social impacts of products, along their life cycles. In the methodology, several issues are considered: processes, actors, geographical characteristics but, in particular, all who have interests in life cycles [6].

The framework is composed of four steps, based on Life Cycle Assessment ISO Standard 14040 [13,14] applied to social issues:

(1). Goal and scope of the analysis

(2). Life Cycle Inventory

(3). Life Cycle Impact Assessment

(4). Interpretation of results

Stakeholders should be present during the development of an SLCA analysis and, consequently, are considered from the point of view of impact analysis.

They can be divided into five groups, and then macro classes can be adapted to the specific case of accommodation; in more detail, they can be grouped as shown in the Stakeholders' classification of the UNEP-SETAC Guidelines [10]. 
In our model, each class of stakeholder has been associated with their objectives and impacts, which identify shape, and modify the boundaries of the system, contributing to its definition.

In this specific analysis, the stakeholders' involvement quantification is heavily influenced by the various sub-categories of impact, as shown in Table 1 [24].

Table 1. Stakeholder Classification from the United Nations Environment ProgrammeSocial Life Cycle Assessment (UNEP-SETAC) Guidelines [10].

\begin{tabular}{|c|c|}
\hline Stakeholder Categories & Subcategories \\
\hline Employees & $\begin{array}{l}\text { 1. Freedom of association and collective bargaining } \\
\text { 2. Child Labor } \\
\text { 3. Working hours } \\
\text { 4. Forced Labor } \\
\text { 5. Equal opportunities/Discrimination } \\
\text { 6. Health and Safety } \\
\text { 7. Fair salary } \\
\text { 8. Social Benefit/Social security }\end{array}$ \\
\hline Local community & $\begin{array}{l}\text { 1. Access to material resources } \\
\text { 2. Access to immaterial resources } \\
\text { 3. Delocalization and Migration } \\
\text { 4. Cultural Heritage } \\
\text { 5. Safe and Healthy living Conditions } \\
\text { 6. Respect of Indigenous rights } \\
\text { 7. Communities engagement } \\
\text { 8. Local Employment } \\
\text { 9. Secure Living Conditions }\end{array}$ \\
\hline Society & $\begin{array}{l}\text { 1. Public commitments to sustainability issues } \\
\text { 2. Contribution to economic development } \\
\text { 3. Prevention \& mitigation of amending conflict } \\
\text { 4. Technology development } \\
\text { 5. Corruption }\end{array}$ \\
\hline Consumer & $\begin{array}{l}\text { 1. Health and Safety } \\
\text { 2. Feedback mechanism } \\
\text { 3. Consumer privacy } \\
\text { 4. Transparency } \\
\text { 5. End of life responsibility }\end{array}$ \\
\hline Value chain actors not including consumers & $\begin{array}{l}\text { 1. Fair competition } \\
\text { 2. Promoting social responsibility } \\
\text { 3. Supplier relationships } \\
\text { 4. Respect of intellectual property rights }\end{array}$ \\
\hline
\end{tabular}

The first step consists in the choice of indicators. As usually, this phase leads to identifying a set of mixed indicators (quantitative, semi-quantitative, and qualitative) with a strong characterization given in relation to the geographical area. The geographical aspects have significantly influenced the results of the SLCA. 
The second phase consists in the preparation of the inventory-defining the most appropriate indicators relating to the sub-categories shown in Table 1.

The international scientific community has defined different criteria with the aim of getting a complete set, in order to meet all the testing requirements.

In this case study, indicators established by Jørgensen were taken into account; they are expressed in a matrix structure for the various impact categories, divided into subcategories as defined by international guidelines, with the necessary adaptations and changes for the contextualization of the case, and properly integrated with the indicators provided by the Guidelines $[13,14]$.

\section{The Methodology: The Questionnaire}

Qualitative and quantitative surveys were conducted. With respect to the quantitative survey, a set of items was adopted as specific questions in the descriptive phase. Considering the exploratory nature of the research, the proposed structure was derived from the authors' original investigation. In this way, a questionnaire was designed and administered. The questionnaire was composed of 28 questions (multiple-choice and open-ended).

The questionnaire was tested, through a pilot survey, on a small sample ( $n=10$ people) of respondents, after which the formulation of some questions was adapted to guarantee clearness and consistency.

The questionnaire was organized in three sections: profiling, general section, and specific session.

The first part, profiling, gathers information on name, geographical location, and, in particular, on the respondent's role within a company. The second part, general section, contains information about the labeling, management system, and description of the structure and additional services.

The specific session was divided into sub-categories, reflecting the categories of stakeholders in the guideline, as shown in Table 2.

Table 2. The Questionnaire Model.

\begin{tabular}{|c|c|}
\hline Stakeholder Theory & Questions \\
\hline -Workers & 1. How many people are engaged? \\
\hline & 2. Usually, how many hours a day are dedicated to the company? \\
\hline & 3. Which type of collaboration agreement do workers have? \\
\hline & 4. What is the average hourly salary? \\
\hline -Local Community and Society & $\begin{array}{c}\text { 5. What are the personal characteristics of the } \\
\text { workforce (age, sex, nationality, } \text { etc.)? }\end{array}$ \\
\hline & 1. How are the resources and raw materials retrieved? \\
\hline & $\begin{array}{c}\text { 3. What is your attitude towards the local community initiatives? } \\
\text { in the area and, if so, do you have ad hoc company policies? }\end{array}$ \\
\hline & $\begin{array}{r}\text { 4. Do you think of contributing to the } \\
\text { development of the local economy? }\end{array}$ \\
\hline & 5. What is the relationship with technological innovation? \\
\hline
\end{tabular}


Table 2. Cont.

\begin{tabular}{|c|c|}
\hline Stakeholder Theory & Questions \\
\hline -Customer & 1. Who is your customer? (Gender, age, characteristics, etc.) \\
\hline & 2. What are the benefits of your services? \\
\hline & 3. Are there regulars? If yes, how often do they return? \\
\hline 4. What is the average stay? \\
\hline 5. What is the average stay? Is a loyal customer \\
given discounts or other benefits?
\end{tabular}

\subsection{The Hypothesized Model for the Case Study}

With the aim to analyze the accommodation facility sustainability, the key variables to be studied are related to the sector criteria, namely:

- Tourists accommodation capacity planning in the geographic area

- Rational use of natural resources (energy, water, soil)

- Natural landscape preservation

- Controlled management and eco-friendly urban waste

- Controlled management and eco-friendly waste water treatment

- Protection of natural habitats

- Respect and sensitivity to local cultures

- Construction and operation of tourism infrastructure in compliance with the environmental characteristics of the area

- Management of eco-friendly roads and local traffic

- Use of products and consumer goods produced by the local community

- Training of tour operators on the cultural and environmental conditions

The main sources of data were direct interviews and monitoring of the structure in a given time slot (three months for the interviews and six months for the monitoring of activities). The requested information was classified according to the categories of stakeholders, and monitored data were calibrated according to the specific sustainability criteria for the sectors mentioned above, with specific reference to sector analysis of the Bed \& Breakfast (B\&B) category, to which the considered structure belongs.

Afterwards, the system of accommodation was taken into account, to detect hotspots and make suggestions for an improvement strategy, enabling management structures to focus on potential causes of unsustainability, in order to reduce or eliminate them.

In this phase the special features connected with the facilities classified as B\&B were particularly outlined. A sector analysis, carried out by several groups at the national level, has shown a fragmented reality; however, the sector is still in a developmental phase, with a wide community of stakeholders that often move in a fragmented way.

Different research projects conducted by the Specific Observatory of the Italian Touring Club, founded in 2002, showed that this phenomenon is growing rapidly, and put in evidence two main categories of stakeholders among those with the highest expectations: customers who benefit from the service, and people who are part of the local community. 
The examined tourist structure is located in the Lazio region of Italy. This area has the highest concentration of $\mathrm{B} \& \mathrm{~B}$ structures in Italy, with a national share of over $10 \%$. The area currently presents 37 accommodation listed as B\&Bs. For these structures, potential customers can be collected into four distinct categories:

(1). Tourists looking for a home treatment, interested to know the area and aspects of life of residents, to feel more similar to them

(2). Tourists in search of the most inexpensive solution

(3). Tourists travelling for business reasons and visitors who are involved in work activities in the area. This category is extremely variable in number, and dependent on the activity in the area during different periods. Sales representatives and consultants are the types of customers that are most present in this class.

(4). Passing tourists just interested in an overnight stay

In this accommodation facility, the data collected for the preparation of the inventory shows that the categories of customers associated with higher frequencies belong to the first and third categories. The category with a higher incidence is the one composed of people travelling for business (more than 50\%).

The choice of a functional unit is an important point of the SLCA. In this case, the functional unit chosen is a temporal functional unit, primarily because in the services analysis it is more complicated to operate as a mass functional unit. Thus, in the functional unit all the activities related to the fruition of a two-day service are included, which corresponds to the average time spent at the facility by customers in recent years.

For the definition of system boundaries were outlined, taking into account the length of stay in the structure (arrival in the structure, permanence, the end of the stay, and departure of the visitor).

The inventory results in the processing of different sources: primary data coming directly from water, electricity, and gas invoices; interviews, realized through the distribution of a questionnaire for customers, and directly conducted with the staff; secondary data analysis from the tourism sector, databases, and external documents.

Due to the peculiarity of the examined case, it was necessary to adapt the existing methodologies to assess the specific aspects of the functional unit considered [27].

\subsection{Social Inventory Analysis}

Sub-categories related to stakeholders, identified as "most impact category", have been considered in the Inventory analysis as specified by Grießhammer [28]. For the evaluation of the category "Workers", "Customers" and "Local Community", we obtained the results shown in Table 3, Table 4 and Table 5. In each table shows the values obtained for each sub-category, with the indication of the consideration of the indicator, the impact and the effect of the impact. 
Table 3. Identification of the parameters of evaluation of the category "Workers".

\begin{tabular}{|c|c|c|c|}
\hline Workers Customers sub-category & Indicators & Impacts & Incidence on value \\
\hline Hours workers & Yes & Positive & Three hours \\
\hline Fair salary & Yes & Positive & $7 €$ per day \\
\hline Social benefits & $\begin{array}{c}\text { Partially } \\
\text { considered }\end{array}$ & Negative & $\begin{array}{c}\text { The small size of the labor } \\
\text { force allows a only partial } \\
\text { consideration of indicator }\end{array}$ \\
\hline
\end{tabular}

For the Customers category, instead, we obtained the results shown in Table 4.

Table 4. Identification of the parameters of evaluation of the category "Customers".

\begin{tabular}{|c|c|c|c|}
\hline Customers sub-category & Indicators & Impacts & Incidence on value \\
\hline Health and Safety & Yes & Positive & $\begin{array}{c}\text { Accommodation } \\
\text { characteristics appropriate }\end{array}$ \\
\hline Feedback & Yes & Positive & Regulars and loyal customers \\
\hline Privacy & Yes & Positive & $\begin{array}{c}\text { Accomodation characteristics } \\
\text { appropriate, all } \\
\text { confidential information }\end{array}$ \\
\hline Transparency & Yes & Positive & $\begin{array}{c}\text { Well-defined and } \\
\text { clear information }\end{array}$ \\
\hline
\end{tabular}

In studying the sub-categories of impact on the Local Community, the categories "Safe and Healthy living Conditions," "Respect of indigenous rights," and "Secure Living Conditions,"- defined by the UNEP-SETAC Guidelines - were excluded, as they were considered not appropriate in relation to the characteristics of the environment and the territory in which the activity is managed [10,29,30].

Table 5. Identification of the parameters of evaluation of the category "Local Community".

\begin{tabular}{|c|c|c|c|}
\hline $\begin{array}{c}\text { Local Community Sub- } \\
\text { Category }\end{array}$ & Indicators & Impacts & Incidence on Value \\
\hline Access to material resources & $\begin{array}{c}\text { Partially } \\
\text { considered }\end{array}$ & Positive & Loyal suppliers \\
\hline Access to immaterial resources & $\begin{array}{c}\text { Partially } \\
\text { considered }\end{array}$ & Positive & Loyal suppliers \\
\hline Migration and delocalization & $\begin{array}{c}\text { Partially } \\
\text { considered }\end{array}$ & Negative & $\begin{array}{c}\text { High rate of migration } \\
\text { in the geographical area and production } \\
\text { outsourcing }\end{array}$ \\
\hline Cultural Heritage & Yes & Negative & $\begin{array}{l}\text { High concentration of cultural and } \\
\text { artistic heritage, not always appreciated } \\
\text { in the geographical area of reference }\end{array}$ \\
\hline $\begin{array}{l}\text { Safe and Healthy Living } \\
\text { Conditions }\end{array}$ & No & - & - \\
\hline Respect of Indigenous Rights & No & - & - \\
\hline
\end{tabular}


Table 5. Cont.

\begin{tabular}{|c|c|c|c|}
\hline $\begin{array}{c}\text { Local Community Sub- } \\
\text { Category }\end{array}$ & Indicators & Impacts & Incidence on Value \\
\hline Community Involvement & Yes & Negative & $\begin{array}{c}\text { Low commitment to local initiatives, } \\
\text { government initiatives for the } \\
\text { enhancement of the B\&B }\end{array}$ \\
\hline Local Employment & Yes & Positive & High rate of unemployment \\
\hline Secure Living Conditions & No & - & - \\
\hline
\end{tabular}

Even when evaluating the secondary data from the general environment, gathered from the main public databases, the three variables do not appear to be relevant to the analysis.

The impact categories related with the procurement of resources and with "migration and relocation" only partially have been taken into account, because, as the B\&B structures are relatively small, they are not able to separately influence the surrounding system.

On the contrary, different considerations can be made if B\&B structures are evaluated as a set of structures of the same class of service. In this case, the variables with the higher impacts are "Cultural heritage," "Community involvement," and "Local Employment," and they can be directly influenced by the individual accommodation.

\section{Results}

The indications that emerged from the interviews were detected on the supply side. A demographic composition of this accommodation facility coincides with the national average data in the field. Ownership and management are composed, in the majority, of women with a high average level of education (tertiary level), and low knowledge of foreign languages [31,32].

An important factor for the evaluation of the impact on the local community is that the structure that previously worked entirely satisfactorily for management resulted in the absence of stable employment. The economic rationale is, therefore, the main thrust to undertake this type of activity [33,34].

The buildings in which the activity is located are independent residences, and that circumstances allow the management to easily monitor the impacts, and take initiatives in the direction of an increasing sustainability, such as: a rationalization of the use of water resources, a differentiation of energy sources (for example, the introduction of photovoltaic panels, in particular for outdoor lighting, that cover about $40 \%$ of the overall energy needs), and finally the installation of an automated heating system — which permits a significant energy saving in winter, being active only in rooms with customers.

Regarding promotion and communication, a remarkable lack of participation in networking initiatives, or being present in different channels of intermediation was noted. The only effective means of promotion and communication is, in fact, word-of-mouth advertising, partly because of the particular type of customer hosted.

Finally, for the "Worker" category, we obtained positive results in all totally considered indicator (three hours for a day for seven Euros paid for hours). With regard to worker law, it is a good result for the reality of accomodation facilities.

The negative impact of indicators on "Cultural Heritage" mostly depends on the lack of participation by the accommodation facilities in the tourism network and the lack of collaboration with 
cultural and artistic organizations, impeding the promotion and development of an area. This assessment is confirmed by the second category considered, also with a negative evaluation, which shows evidence of a lack of commitment to territorial initiatives.

In conclusion, the two underlined variables seemed to be the only ones with a critical situation and negative impacts. The assessment of the social impacts of a product/service - through the assessment of its life cycle, which is still at an early stage of diffusion-lacks proper quantitative indicators. The main problem is related to the difficulty in linking social indicators with the functional unit of the system/product to make them manageable and significant. Precisely for this reason, the actual qualitative and semi-quantitative approaches suffer from a lack of quantitative and well-defined indicators This does not mean that the model is not operative. The effectiveness of the model structure has been widely demonstrated in literature and through the empirical analysis carried out on specific products.

\section{Conclusions}

Social sustainability is a priority and competitive key factor for enterprise in all economic sectors, because it increases the added value of a company — especially in terms of image and credibility - in addition to improving the relationship with all stakeholders.

The purpose of this paper has been to demonstrate that while there remain points still to be improved, SLCA is a methodology for assessment comprehensive and effective. The concept of social sustainability has evolved in multiple aspects. The level of analysis has moved from the macro-societal level to the organizational level through the application of the methodology to a specific business in the tourism sector. We wanted to concentrate on an accommodation facility, through the simultaneous application of existing Social Life Cycle Assessment tools in order to point out the social criticalities.

In particular, the SLCA application presented in this paper has stressed the importance of the relations which should exist between the tourist accommodation services and the local community taken as a whole, with particular reference to local administrative structures and company networks. Finally, the importance of this type of relationship is reinforced by the increasing demand from customers looking for a different kind of tourism experience which presents a familiar atmosphere, directed to the local characteristics.

In conclusion, we can say that SLCA can be a methodology that complements existing CSR tools and assessment of social sustainability, because it is comprehensive and evaluates the entire life cycle of the product/service.

\section{Conflict of Interest}

The authors declare no conflict of interest.

\section{References}

1. Lee, M.A. Review of the theories of corporate social responsibility: Its evolutionary path and the road ahead International. J. Manag. Rev. 2008, 10, 53-73. 
2. Freeman, E.R. Strategic Management: A Stakeholder Approach; Pitman: Boston, MA, USA, 1984.

3. SAI (Social Accountability International). Abridged Guidance-2008 Standard, February 2011. Available online: http://www.sa-intl.org/index.cfm?fuseaction=Page.ViewPage\&PageID=1095 (accessed on 15 July 2013).

4. Mueller, M.; Gomes dos Santos, V.; Seuring, S. The contribution of environmental and social standards towards ensuring legitimacy in supply chain governance. J. Bus. Eth. 2009, 89, 509-523.

5. Benoît, C.; Norris, G.; Valdivia, S.; Ciroth, A.; Moberg, Å.; Bos, U.; Prakash, S.; Ugaya, C.; Beck, T. The guidelines for social life cycle assessment of products: Just in time! Inter. J. Life Cycle Ass. 2010, 15, 156-163.

6. Russo, A.; Perrini, F. Investigating Stakeholder Theory and Social Capital: CSR in Large Firms and SMEs. J. Business Ethics 2010, 91, 207-221.

7. Arcese, G.; Ippolito, C.; Merli, R. Social Life Cycle Assessment e Turismo: Applicazione ad una Struttura Ricettiva. Available online: www.forumeditrice.it/percorsi/scienza-e-tecnica/varia/ilcontributo-delle-scienze-merceologiche-per-un-mondo-sostenibile-contribution-of-commodityscience-to-a-sustainable-world/1sezione_alimenti_1-210.pdf (accessed on 15 July 2013).

8. De Camillis, C.; Raggi, A.; Petti, L. Tourism LCA: State-of-the-art and perspectives. Int. J. Life Cycle Ass. 2010, 15, 148-155.

9. Kloepffer, W. Life cycle assessment of products. Int. J. Life Cycle Ass. 2008, 13, 89-95.

10. UNEP. Guidelines for Social Life Cycle Assessment of Products; UNEP-SETAC Life-Cycle Initiative: Paris, France, 2009.

11. Fava, J.; Hall, J. Why Take a Life Cycle Approach? UNEP/SETAC Publication: Paris, France, 2004. Available online: http://www.unep.fr/scp/lcinitiative/publications/ (accessed on 15 March 2013).

12. Petti, L.; Campanella, P. The Social LCA: the State of Art of An Evolving Methodology. In The Annals of The "Ştefan cel Mare" University of Suceava; Fascicle of the Faculty of Economics and Public Administration: Suceava, Romania, 2010; Volume 9.

13. ISO. Environmental Management-Life Cycle Assessment-Principles and Framework (ISO 14040); ISO: Geneva, Switzerland, 2006.

14. ISO. Environmental Management-Life Cycle Assessment-Requirements and Guidelines (ISO 14044); ISO: Geneva, Switzerland, 2006.

15. Weidema, B.P. ISO-14044 also applies to social LCA. Int. J. Life Cycle Ass. 2005, 10, 381-389.

16. Finkbeiner, M.; Schau, E.M.; Lehmann, A.; Traverso, M. Towards life cycle sustainability assessment. Sustainability 2010, 2, 3309-3322.

17. Reitinger, C.; Dumke, M.; Barosevcic, M.; Hillerbrand, R. A conceptual framework for impact assessment within SLCA. Int. J. Life Cycle Ass. 2011, 16, 380-388.

18. Hauschild, M.Z.; Dreyer, L.C.; Jørgensen, A. Assessing Social Impacts in a Life Cycle Perspective-Lessons Learned. CIRP Ann. Manuf. Technol. 2008, 57, 21-24.

19. Weidema, B.P. The integration of economic and social aspects in life cycle impact assessment. Int. J. Life Cycle Ass. 2006, 11, 89-96. 
20. Jørgensen, A.; Le Bocq, A.; Nazarkina, L.; Hauschild, M.Z. Methodologies for social life cycle assessment. Int. J. Life Cycle Ass. 2008, 13, 96-103.

21. Jørgensen, A.; Finkbeiner, M.; Jørgensen, M.S.; Hauschild, M.Z. Defining the baseline in social life cycle assessment. Int. J. Life Cycle Ass. 2010, 15, 376-384.

22. Burkart, A.J.; Medlik, S. Tourism: Past, Present and Future; Heinemann Educational Books: London, United Kingdom, 1972; Volume 2, xiv-366.

23. Font, X. Environmental certification in tourism and hospitality: Progress, process and prospects. Tour. Manag. 2002, 23, 197-205.

24. Lepp, A.; Harris, J. Tourism and national identity in Uganda. Int. J. Tour. Res. 2008, 10, 525-536.

25. Arcese, G.; Martucci, O. Gestione del Rischio e Sostenibilità globale: Un Tentativo di Integrazione tra Strumenti di Risk Management e Social Life Cycle Assessment. In Valutazioni di sostenibilità di Tecnologie: Quale Ruolo per la LCA? (Assessments of Sustainability Technologies: What Role for the LCA)-“Risk Management and Global Sustainability: An Attempted Integration of Risk Management Tools and Social Life Cycle Assessment; Proceedings of Ecomondo, Rimini, 3-6 November 2010; Maggioli Eds.: Bologna, Italy, 2010.

26. Bartolomeo, M.; Malaman, R.; Pavan, M.; Sammarco, G. Il bilancio ambientale d'impresa, "The environmental accounti for business"; Eds Il Sole 24 Ore Libri-Pirola: Milano, Italy, 1995.

27. Parent, J.; Cucuzzella, C.; Revéret, J.P. Impact assessment in SLCA: sorting the sLCA methods according to their outcomes. Int. J. Life Cycle Ass. 2010, 15, 164-171.

28. Gauthier, C. Measuring corporate social and environmental performance: The extended life-cycle assessment. J. Bus. Eth. 2005, 59, 199-206.

29. Hunkeler, D. Societal LCA methodology and case study. Int. J. Life Cycle Ass. 2006, 11, 371-382.

30. Jørgensen, A.; Hauschild, M.Z.; Jørgensen, M.S.; Wangel, A. Relevance and feasibility of social life cycle assessment from a company perspective. Int. J. Life Cycle Ass. 2009, 14, 204-214.

31. Grießhammer, R.; Benoît, C.; Dreyer, L.C.; Flysjö, A.; Manhart, A.; Mazijn, B.; Méthot, A.; Weidema, B. Feasibility Study: Integration of Social Aspects into LCA; Ghent University paper; Ghent University: Ghent, Belgium, 2006.

32. Dreyer, L.C.; Hauschild, M.Z.; Schierbeck, J. A framework for social life cycle impact assessment. Int. J. Life Cycle Ass. 2006, 11, 88-97.

33. Kruse, S.A.; Flysjö, A.; Kasperszyk, N.; Scholz, A.J. Socioeconomic indicators as a complement to life cycle assessment-an application to salmon production systems. Int. J. Life Cycle Ass. 2008, 14, 8-18.

34. Hendrickson, C.T.; Lave, L.B.; Matthews, S.H. Environmental Life Cycle Assessment of Goods and Services: An Input-Output Approach; Routledge, Taylor and Francis Publisher: London, England, 2006.

(C) 2013 by the authors; licensee MDPI, Basel, Switzerland. This article is an open access article distributed under the terms and conditions of the Creative Commons Attribution license (http://creativecommons.org/licenses/by/3.0/). 